\title{
Undang-Undang Nomor 21 Tahun 2007 tentang Pemberantasan Tindak Pidana Perdagangan Orang dalam Perspektif Hukum Islam
}

\author{
Neni Nuraeni \& Dede Kania
}

\begin{abstract}
The 21/2007 of Human Traficking Act in the Perspective of Islamic Law. Human Traffickingis one of the most common crimes occurs in Indonesia. To eradicate this crime, the government issued the 21/2007 of Human Trafficking Act (UU PTPPO). The statue sanctions persons committing the crime and providing protection to witnesses and victims. The law accomodate a number of penalties for the perpetrators of this crime, ranging from principal punishment, in the form of imprisonment and fine, to additional criminal and ballast. Although Islamic law does not explicitly regulate this crime, it is clearly contrary to Islamic principles of freedom, independence, equality and human dignity.
\end{abstract}

Keywords: Indonesia, human trafficking Act, Islamic law, humanity

\begin{abstract}
Abstrak: Undang-Undang Nomor 21 Tabun 2007 tentang Pemberantasan Tindak Pidana Perdagangan Orang dalam Perspektif Hukum Islam. Perdagangan orang (buman trafficking) merupakan salah satu kejahatan yang banyak terjadi di Indonesia. Untuk mengatasi kejahatan tersebut, pemerintah menerbitkan Undang-Undang Nomor 21 Tahun 2007 tentang Pemberantasan Tindak Pidana Perdagangan Orang (UU PTPPO). Undang-undang tersebut mengatur tentang sanksi pidana bagi pelaku kejahatan perdagangan orang dan memberikan perlindungan kepada saksi dan korban. Terdapat sejumlah jenis ancaman hukuman untuk pelaku kejahatan ini, mulai dari pidana pokok berupa pidana penjara dan pidana denda, hingga pidana tambahan dan pemberat. Meski hukum Islam tidak mengatur tentang kejahatan ini, namun perbuatan kriminal ini jelas bertentangan dengan prinsip-prinsip Islam tentang kebebasan, kemerdekaan, kesetaraan dan penghargaan harkat martabat manusia.
\end{abstract}

Kata Kunci: Indonesia, perdagangan orang, hukum Islam, kemanusiaan

Fakultas Syariah dan Hukum UIN Sunan Gunung Djati

Jl. A.H. Nasution No. 105, Cipadung, Cibiru, Kota Bandung, Jawa Barat 40614

E-mail: nuraeniabdul@gmail.com 


\section{Pendahuluan}

Undang-Undang Nomor 21 Tahun 2007 tentang Pemberantasan Tindak Pidana Perdagangan Orang (selanjutnya disebut UU PTPPO) lahir sebagai upaya pemerintah untuk mengantisipasi maraknya perdagangan orang (buman trafficking). Para aktivis hak asasi manusia dan aktivis perempuan mendesak pemerintah mengenai pentingnya sebuah undangundang yang membahas secara khusus permasalahan perdagangan orang. Desakan ini lebih didasarkan pada realita bahwasannya Indonesia merupakan salah satu negara yang menjadi lokasi perdagangan orang terbesar di wilayah Asia Tenggara.

Jalur trafficking di Asia Tenggara melibatkan enam negara, yaitu Indonesia, Malaysia, Singapura, Thailand, Vietnam, dan Filipina. Empat dari enam negara tersebut, yakni Indonesia, Thailand, Filipina, dan Vietnam merupakan negara asal dari korban perdagangan orang, adapun Malaysia hanya sebagian kecil. Alur penyebaran tujuan perdagangan orang meliputi Indonesia, Malaysia, Singapura, Filipina, dan Thailand. ${ }^{1}$ Jumlah korban trafficking-pun semakin memprihatinkan. Indonesia merupakan peringkat ketiga terbesar dalam jumlah kasus trafficking di Asia. ${ }^{2}$ Menurut data Mabes Polri, angka kasus trafficking di Indonesia setiap tahunnya terus meningkat dengan mayoritas korban adalah perempuan, ${ }^{3}$ satu perempuan bahkan dibanderol seharga Rp. 500.000,- (lima ratus ribu rupiah). ${ }^{4}$

Hadirnya UU PTPPO dilandasi pemikiran bahwa: (1) perdagangan orang merupakan tindakan yang bertentangan dengan harkat dan martabat manusia, serta melanggar hak asasi manusia; (2) bahwa perdagangan orang telah meluas dalam bentuk jaringan yang terorganisasi maupun tidak, sehingga menjadi ancaman terhadap masyarakat, bangsa, dan negara maupun luar negeri; dan (3) bahwa keinginan untuk mencegah

${ }^{1}$ J. Azlaini Agus (Komisi III DPR RI, Pansus RUU PTPPO DPR RI) pada (Seminar Nasional Strategi Pemberantasan Tindak Pidana Perdagangan Orang dalam Perspektif Lokal, Nasional, dan Internasional, Universitas Jember, 27 Juni 2009).

${ }^{2}$ US Departemen of Justice, “Trafficking in Person Report" (Washington: US Departemen of Justice, 2002), h. 10.

${ }^{3}$ ANTARA News, Senin, 23 April 2012.

${ }^{4}$ Bandung Ekspress, Kamis, 12 Oktober 2012. 
dan menanggulangi tindak pidana perdagangan orang didasarkan pada nilai-nilai luhur, komitmen nasional dan internasional untuk melakukan upaya pencegahan sejak dini, penindakan terhadap pelaku, perlindungan korban, dan peningkatan kerja sama.

Sebelum UU PTPPO lahir, didahului oleh kebijakan pemerintah berupa ketentuan peraturan perundang-undangan yang terkait dengan persoalan perdagangan perempuan dan anak, seperti termaktub dalam KUHP dan Undang-Undang Nomor 39 Tahun 1999 tentang Hak Asasi Manusia. Pada tanggal 30 Desember 2002, keluar Keppres Nomor 88 Tahun 2002 tentang Rencana Aksi Nasional Penghapusan Perdagangan (Trafficking) Perempuan dan Anak (RAN-P3A). Untuk menjamin implementasi RAN-P3A, pemerintah membentuk Gugus Tugas Nasional. Kemudian pada tahun 2007, ditetapkan Undang-Undang Nomor 21 Tahun 2007 tentang Pemberantasan Tindak Pidana Perdagangan Orang.

Dasar pembentukan UU PTPPO adalah Undang-Undang Dasar 1945 Pasal 20, Pasal 21, dan Pasal 28B ayat (2), Convention on the Elimination of All Forms of Discrimination Against Women (CEDAW) yang telah diratifikasi Indonesia melalui Undang-Undang Nomor 7 Tahun 1984, dan Undang-Undang Nomor 23 Tahun 2002 tentang Perlindungan Anak. Dari beberapa definisi tentang perdagangan orang yang diatur dalam berbagai instrumen hukum, memberikan gambaran tentang perdagangan orang sebagai bentuk tindak pidana yang sangat melanggar hak asasi manusia, sehingga penting dilakukan berbagai tindakan yang dapat mengurangi dan melindungi korban perdagangan manusia. ${ }^{5}$ Selain

5 Terkait perdagangan orang, telah banyak artikel yang membahasnya, di antaranya Yohanes Suhardin. "Tinjauan Yuridis Mengenai Perdagangan Orang dari Perspektif Hak Asasi Manusia." Mimbar Hukum-Fakultas Hukum Universitas Gadjah Mada 20, no. 3 (2008): h. 473-486. Maslihati Nur Hidayati. "Upaya Pemberantasan dan Pencegahan Perdagangan Orang Melalui Hukum Internasional dan Hukum Positif Indonesia." Jurnal Al-Azhar Indonesia Seri Pranata Sosial 1, no. 3 (2012): h. 163-175. Riswan Munthe. "Perdagangan Orang (Trafficking) Sebagai Pelanggaran Hak Asasi Manusia." JUPIIS: Jurnal Pendidikan Ilmu-ilmu Sosial 7, no. 2 (2015): h. 184-192. Dwita Puspita Sari, and Dessy Artina. "Penggunaan Sarana Non Penal oleh Pusat Pelayanan Terpadu Pemberdayaan Perempuan dan Anak Provinsi Riau dalam Pencegahan Tindak Pidana Perdagangan Anak di Bawah Umur Berdasarkan Undang-Undang Nomor 35 Tahun 2014 Atas Perubahan Undang-Undang Nomor 23 Tahun 2002 Tentang Perlindungan Anak." Jurnal Online Mahasiswa (JOM) Bidang Ilmu Hukum 4, no. 2 (2018): h. 1-15. Syaifullah Yophi Ardianto. "Perlindungan Hukum Terhadap Anak Sebagai Korban dari Tindak Pidana 
itu perumusan UU PTPPO ini juga berdasarkan Konvensi Palermo Tahun 2000 dan Protokol Perserikatan Bangsa-Bangsa untuk pencegahan, pemberantasan, dan pemidanaan pelaku perdagangan manusia khususnya perempuan dan anak. ${ }^{6}$

Di Indonesia, pengaturan mengenai perdagangan orang terdapat dalam UUD 1945 Pasal 28A,28G, 28I (1), Undang-Undang Nomor 39 Tahun 1999 tentang Hak Asasi Manusia Pasal 20, dan secara tegas dalam Undang-Undang Nomor 21 Tahun 2007 tentang Pemberantasan Tindak Pidana Perdagangan Orang. Namun, terdapat beberapa aspek

Perdagangan Orang di Kota Pekanbaru.” Jurnal Ilmu Hukum Riau 3, no. 2 (2013). Ayu Amalia Kusuma. "Efektivitas Undang-Undang Perlindungan Anak dalam Hubungan dengan Perlindungan Hukum Terhadap Anak Korban Perdagangan Orang di Indonesia." Lex Et Societatis 3, no. 1 (2015). Daniel Andreo. "Analisis Juridis Terhadap Pertanggungjawaban Pidana Pelaku Percobaan Tindak Pidana Perdagangan Orang Menurut Undang-Undang Nomor 21 Tahun 2007 (Putusan Pengadilan Negeri Medan Nomor 1.642/Pid. B/2009/PN. Medan.” Jurnal Mahupiki 2, no. 01 (2012). Shinta Agustina. "Perdagangan Perempuan dan Anak Sebagai Kejahatan Transnasional: Permasalahan dan Penanggulangannya di Indonesia." Jurnal Hukum Pro Justitia 24, no. 1 (2006). Nelsa Fadilla. "Upaya Perlindungan Hukum Terhadap Anak Sebagai Korban Tindak Pidana Perdagangan Orang." Jurnal Hukum dan Peradilan 5, no. 2 (2016): h. 181-194. Henny Nuraeny. "Penyuluhan Hukum Mengenai Undang-Undang Nomor 21 Tahun 2007 Tentang Pemberantasan Tindak Pidana Perdagangan Orang Bagi Guru Bimbingan Konseling dan Siswa/Siswi SMK/SMA/ MA Se-kabupaten Cianjur." Journal of Empowerment 1, no. 1 (2017): h. 23-36. Erdianto Effendi. "Pemberantasan Perdagangan Orang dengan Sarana Hukum Pidana." Jurnal Cita Hukum 1, no. 1 (2013). Sanofta DJ Gunting, Nurmala Waty, and Alwan Alwan. "Kebijakan Hukum Pidana dalam Menanggulangi Tindak Pidana Perdagangan Orang (Human Trafficking)." Jurnal Mahupiki 2, no. 1 (2013). Wardani, Ferica, and Faisyal Rani. "Peran Bali Process On People Smuggling, Traficking In Person And Related Transnational Crime (Bali Process) dalam Menangani Penyelundupan Manusia di Indonesia Pada Tahun 2008-2013." Jurnal Online Mahasiswa (JOM) Bidang Ilmu Sosial dan Ilmu Politik 2, no. 2 (2015): h. 1-15. Nikodemus Niko. "Kemiskinan Sebagai Penyebab Strategis Praktik Humman Trafficking di Kawasan Perbatasan Jagoi Babang (Indonesia-Malaysia) Kalimantan Barat." In Prosiding Seminar Nasional Indocompac. 2016. Ike Sylvia. "Faktor Pendorong dan Penarik Perdagangan Orang (Human Trafficking) di Sumatera Barat." Humanus 13, no. 2 (2014): h. 193-202. Perdana Eliakhim Manalu, Suhaidi Suhaidi, Muhammad Hamdan, and Hasim Purba. "Sanksi Pidana Terhadap Pelaku Tindak Pidana Perdagangan Orang (Studi Beberapa Putusan Pengadilan Negeri di Indonesia).” USU Law Journal 2, no. 3 (2014): h. 176-189. Henny Nuraeny, and Tanti Kirana Utami. "The Victim Handling Model Of Human Trafficking Through Economic Independence.” Jurnal Dinamika Hukum 16, no. 2 (2016): h. 120-124. Linda Jayanti, Steven R. Sentinuwo, Oktavian A. Lantang, and Agustinus Jacobus. "Analisa Pola Penyalahgunaan Facebook Sebagai Alat Kejahatan Trafficking Menggunakan Data Mining." Jurnal Teknik Informatika Universitas Sam Ratulangi 8, no. 1 (2016). Siti Hariti Sastriyani. "Perlindungan Perempuan dan Anak Korban Trafficking di Kabupaten Kapuas Hulu.” Marwah: Jurnal Perempuan, Agama dan Jender 9, no. 2 (2010): h. 114-133.

${ }^{6}$ Syarif Hasyim Azizurrahman, "Pembaharuan Kebijakan Pidana Kejahatan Perdagangan Orang (Studi di Wilayah Perbatasan Kalimantan Barat-Sarawak)," Jurnal Yustisia, no. 89 (MeiAgustus 2014): h. 88. 
dalam Undang-Undang Nomor 21 Tahun 2007, yang tidak sejalan dengan hukum Islam, sebagai salah satu komponen dan sistem hukum nasional. Hukum Islam telah menggariskan beberapa ketentuan mengenai perdagangan orang.

\section{Kritik Hukum Islam terhadap Undang-Undang Nomor 21 Tahun 2007 tentang Pemberantasan Tindak Pidana Perdagangan Orang Substansi UU PTPPO}

Undang-Undang Nomor 21 Tahun 2007 tentang Pemberantasan Tindak Pidana Perdagangan Orang memiliki kelebihan dan kekurangan. Terdapat beberapa kelebihan undang-undang ini. Pertama, memiliki sanksi hukum yang jelas bagi pelaku kejahatan, dan juga daya jangkaunya meliputi suatu perusahaan atau korporasi sampai pada oknum penyelenggara negara yang melakukan tindak pidana perdagangan orang.

Kedua, UU PTPPO ini telah memenuhi tiga unsur penting pembuatan undang-undang, yaitu unsur filosofis, sosiologis, dan yuridis. Dilihat dari unsur filosofis, UU PTPPO merupakan peraturan yang dikehendaki untuk menjaga ketertiban dan kepentingan bersama. Dilihat dari aspek sosiologis, UU PTPPO menjamin ketertiban masyarakat. Sedangkan jika dilihat dari unsur yuridis, UU PTPPO memiliki landasan hukum dari undang-undang yang ada di atasnya, yaitu UUD 1945.

Ketiga, UU PTPPO memiliki sinkronisasi secara vertikal dengan undang-undang yang ada di atasnya, yaitu UUD 1945, khususnya Pasal 28B ayat (2). Selain itu pengaturan UU PTPPO juga memiliki keserasian dengan Undang-Undang Nomor 23 Tahun 2003 tentang Perlindungan Anak, dan Undang-Undang Nomor 39 Tahun 1999 tentang Hak Asasi Manusia.

Setidaknya terdapat empat hal yang perlu disempurnakan dari UU PTPPO, yaitu dalam kualifikasi delik, jenis pemidanaan yang diancamkan, tujuan pemidanaan, dan perlindungan hak anak.

Pertama, UU PTPPO tidak menegaskan kualifikasi delik kejahatan dan pelanggaran. Hal tersebut dapat menimbulkan masalah karena UU PPTPPO sebagai undang-undang yang bersifat lex specialis dari KUHP, tetapi terkait pada aturan umum dalam KUHP mengenai akibat yuridis 
dari pembedaan antara "kejahatan" dan "pelanggaran". Selain itu pembuat undang-undang juga tidak membedakan akibat hukum atau pemidanaan untuk "percobaan" dan "pembantuan", karena ancaman pidana untuk percobaan dan pemidanaan adalah sama dengan pelaku delik perdagangan manusia sebagaimana diatur dalam Pasal 10 dan 11 UU PTPPO. Akibat hukum dari pembedaan antara delik "kejahatan" dan "pelanggaran" bukan hanya pada masalah percobaan dan pembantuan, melainkan juga dalam concursus, daluwarsa penuntutan dan pelaksanaan pidana, dan dalam pemberlakuan asas nasionalitas aktif, sebagaimana diatur dalam Pasal 5 ayat (1) ke-2 KUHP. Pasal 10 UU PTPPO memang mengatur tentang delik percobaan dan pembantuan, namun hanya untuk tindak pidana sebagaimana diatur dalam Pasal 2, Pasal 3, Pasal 4, Pasal 5, dan Pasal 6. Adapun Pasal 19 s.d. Pasal 24 tidak ada pengaturan mengenai delik tersebut.

Kedua, secara umum ancaman pidana bagi pelaku TPPO dalam UU PTPPO adalah pidana penjara dan denda. Padahal pidana penjara tidak sepenuhnya cocok bagi semua jenis kejahatan perdagangan orang. Di samping kurang mencerminkan keadilan, pidana penjara juga hanya akan membebani anggaran negara. Menurut penulis, harus dipertimbangkan ancaman yang paling berat, yaitu pidana mati, terhadap delik perdagangan orang tingkat delik yang berat. Pidana penjara hanya dijatuhkan bagi tingkatan delik sedang atau ringan

Ketiga, tujuan pemidanaan yang terdapat dalam UU PTPPO belum menjerakan pelaku, terbukti dengan semakin maraknya korban perdagangan manusia.

Keempat, UU PTPPO mengabaikan hak anak. Undang-undang tersebut hanya memuat aturan perdagangan orang dengan korban anak, namun tidak diatur secara spesifik tentang perdagangan anak. Padahal kasus perdagangan orang dengan korban anak-anak tidak kalah banyak jumlahnya dibandingkan dengan korban dewasa.

Selain substansi secara keseluruhan, terdapat beberapa pasal dari UU PTPPO yang belum sesuai dengan prinsip hukum pidana Islam. Misalnya dalam hal pertanggungjawaban pidana (Pasal 6), perbantuan, percobaan, perencanaan, dan pemufakatan jahat (Pasap 10 dan 11), jenis 
pidana (Pasal 2,3,4,5,6, 12 UU PTPPO), dan kulifikasi kejahatan dan pelanggaran, serta kurang diakomodirnya hak anak.

Prinsip pertanggungjawaban pidana yang dianut UU PTPPO sebagaimana dimuat dalam Pasal 6 PTPPO adalah prinsip strict lialibility atau absolute liability (pertanggungjawaban mutlak). Pertanggungjawaban pidana dalam Pasal ini hanya melihat akibat dari perbuatan pelaku, baik disengaja maupun tidak disengaja. Sehingga tersirat dalam Pasal ini ajaran erfolsghaftung. Barda Nawawi Arief menjelaskan bahwa erfolsghaftung adalah pertanggungjawaban terhadap akibat yang tidak dituju/tidak dikehendaki/disengaja. ${ }^{7}$

Pandangan ini membuka pemahaman yang sempit mengenai kesalahan. Kesalahan bukan hanya dipandang sebagai masalah psikologis pembuat. Akibatnya unsur kesengajaan dan kealpaan hanya dipandang pertanda adanya kesalahan. ${ }^{8}$ Konsekuensinya dalam perumusan tindak pidana tidak harus ditegaskan unsur "dengan sengaja" atau unsur "karena kealpaan” sebagai unsur tindak pidana. Kata dengan sengaja dalam rumusan delik merupakan alat bantu dalam menafsirkan ketentuan delik. Kesengajaan dan kealpaan hanya merupakan pertanda adanya kesalahan, sehingga bukanlah kesalahan itu sendiri. Kesalahan itu ada jika kelakuan tidak sesuai dengan norma yang diterapkan. Sepanjang norma hukum menentukan bahwa pelaku dapat dicela karena melakukan tindak pidana, maka terdapat kesalahan pada diri pelaku. Apabila UndangUndang menetapkan suatu tindak pidana dipertanggungjawabkan secara strict, maka pada pelakunya tetap dipandang memiliki kesalahan, sekalipun tidak ditinjau lebih jauh apakah kesengajaan atau kealpaan yang meliputi batinnya. Hal ini berbeda dengan ketentuan dalam hukum pidana Islam, aspek seseorang yang dapat disebut sebagai pelaku suatu tindak pidana harus memenuhi ketentuan tertentu. Secara umum ada tiga syarat yang dapat menjadikan seseorang harus mempertanggungjawabkan tindakannya. Ketiga syarat tersebut adalah: (1) adanya perbuatan yang dilarang; (2) perbuatan itu dikerjakan dengan kemauan sendiri; dan (3)

${ }^{7}$ Barda Nawawi Arief, Pembaharuan Hukum Pidana dalam Perspektif Kajian Perbandingan (Bandung: Citra Aditya Bhakti, 2005), h. 275.

${ }^{8}$ Barda Nawawi Arief, Pembaharuan Hukum Pidana dalam Perspektif Kajian Perbandingan, h. 82. 
pelaku mengetahui akibat perbuatannya itu. ${ }^{9}$

Pertanggungjawaban pidana (al-masûliyyah al-jinâiyyah) muncul apabila manusia melanggar hak-hak orang lain, baik perorangan maupun hak masyarakat. Berdasarkan ketiga syarat pertanggungjawaban pidana, tidak semua perbuatan pidana dapat dimintai pertanggungjawaban. Karena apabila pelaku kejahatan tidak punya pilihan dalam melakukan kejahatan tersebut, seperti karena ia adalah orang gila atau anak kecil maka ia tidak bisa diminta pertanggungjawaban pidana. ${ }^{10}$ Di dalam hukum pidana Islam, perbuatan harus diketahui mukallaf dengan sempurna. ${ }^{11}$ Pendapat ini berdasarkan firman Allah Swt. dalam Q.s. al-Najm [53]: 39 yang berbunyi:

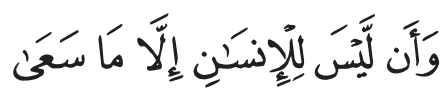

Dan bahwasanya seorang manusia tiada memperoleh selain apa yang telah diusahakannya.

Kata الاماسعى mengandung arti kesengajaan atau atas dasar pengetahuannya. Oleh karena itu, menurut hukum Islam, seseorang akan diberi balasan, baik berupa hukuman atau imbalan sesuai dengan hasil perbuatan yang sengaja dilakukannya. Kemudian sesuai dengan hadits:

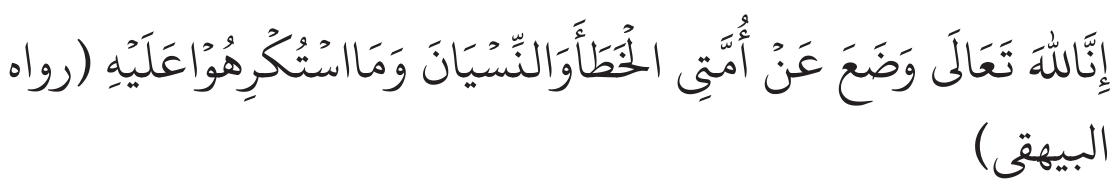

Sesungguhnya Allah mengampuni umatku atas perbuatan yang dilakukan karena kekeliruan, lupa, dan apa yang dipaksakan atasnya. (H.r. Baihaqî). ${ }^{12}$

Berdasarkan hadis di atas, Allah Swt. akan memaafkan atau membebaskan manusia dari tuntutan hukum jika melakukan perbuatan disebabkan tersalah, lupa, dan karena terpaksa. Namun demikian, hukum Islam

9 Ahmad Hanafi, Asas-asas Hukum Pidana Islam (Jakarta: Bulan Bintang, 1990), h. 154.

${ }^{10}$ Topo Santoso, Menggagas Hukum Pidana Islam: Penerapan Syariat Islam dalam Konteks Modernitas (Bandung: Asy-Syaamil Press \& Grafika, 2001), h. 172.

${ }^{11}$ A. Djazuli, Figh Jinayah (Upaya Menanggulangi Kejahatan dalam Islam) (Jakarta: PT Raja Grafindo Persada, 2000), h. 242.

${ }^{12}$ Jalâl al-Dîn al-Suyûthî, al-Jâmi'al-Shaghîr, 1 (Bayrût: Dâr al-Fikr, 73), h. 73. 
mengatur tentang asas tersalah yakni ketidakhatian dan ketidakwaspadaan. Setiap perbuatan tersalah tidak dijatuhi hukuman, karena tersalah telah menghapus salah satu unsur pidana, yaitu unsur kesengajaan. Hanya saja terhapusnya pertanggungjawaban pidana karena tidak adanya salah satu unsur pidana tidak menghalangi pertanggungjawaban secara perdata, karena kaidah hukum Islam menetapkan bahwa darah dan harta benda dilindungi dan mendapat jaminan keselamatan, sehingga alasan-alasan syar'i tidak bertentangan (tidak menghapuskan) jaminan keselamatan tersebut. Penerapan asas tersalah dalam hukum pidana Islam merupakan penggantian kerugian secara mutlak. Kemaslahatan masyarakat menjadi pertimbangan dalam penjatuhan hukuman atas kasus tersalah.

Oleh karena itu, syar $i$ menjatuhkan hukuman atas tindak pidana tersalah yang acap kali mewujudkan kemaslahatan masyarakat yang dapat membuat seseorang menjadi hati-hati sehingga tindak pidana jenis ini menjadi berkurang. Kendati demikian, tidak disyaratkan terjadinya kelalaian untuk pertanggungjawaban pelaku di semua keadaan tersalah. Terjadinya kelalaian hanya disyaratkan pada keadaan al-khatha al-mutawallid (tersalah yang terlahir dari suatu perbuatan yang tidak dilarang/mubah atau perbuatan pelaku yang disangka tidak dilarang).

\section{Kritik Terhadap Pasal 9}

Pasal 9 Undang-Undang Nomor 21 Tahun 2007 mengatur tentang sanksi pidana yang dapat dikenakan kepada setiap orang yang berusaha menggerakan orang lain supaya melakukan tindak pidana perdagangan orang, namun, tindak pidana itu tidak terjadi. Pasal 9 secara lengkap berbunyi:

Setiap orang yang berusaha menggerakkan orang lain supaya melakukan tindak pidana perdagangan orang, dan tindak pidana itu tidak terjadi, dipidana dengan pidana penjara paling singkat 1 (satu) tahun dan paling lama 6 (enam) tahun dan pidana denda paling sedikit Rp. 40.000.000,00 (empat puluh juta rupiah) dan paling banyak Rp. 240.000.000,00 (dua ratus empat puluh juta rupiah).

Rumusan tindak pidana dalam Pasal 9 adalah: (1) berusaha; (2) menggerakkan orang lain; (3) supaya melakukan tindak pidana perdagangan orang; dan (4) tindak pidana itu tidak terjadi. Pasal 
ini memberikan pengaturan mengenai penggerak dari tindak pidana perdagangan orang, tetapi tidak dijelaskan maksud menggerakkan orang lain di dalamnya. Apabila dirujuk kepada Pasal 55 ayat (1) sub 2 KUHP, maka maksud dari pelaku tindak pidana adalah: (1) mereka yang melakukan, yang menyuruh melakukan, dan yang turut serta melakukan perbuatan; dan (2) mereka yang memberi atau menjanjikan sesuatu dengan menyalahgunakan kekuasaan atau martabat, dengan kekerasan, ancaman atau penyesatan, atau dengan memberi kesempatan, sarana atau keterangan, sengaja menganjurkan orang lain supaya melakukan perbuatan. Ketidakjelasan arti "menggerakkan" dapat menimbulkan multi tafsir yang pada akhirnya mengakibatkan kepastian hukum. Padahal, sesuai Pasal 6 butir (i) Undang-Undang Nomor 12 Tahun 2011, materi muatan peraturan perundang-undangan harus mencerminkan asas kepastian hukum.

Selanjutnya, dalam Pasal 9 terdapat frasa, "tindak pidana itu tidak terjadi”. Di dalam hukum pidana Islam, apabila suatu tindak pidana masih berupa proses yang belum ditindaklanjuti dengan proses selanjutnya kemudian dihentikan oleh orang yang merencanakan, maka proses tersebut masuk ke dalam proses perencanaan. Konsekuensi dari masuknya proses perencanaan dan pemufakatan ke dalam fase pemikiran dan perencanaan dalam konteks hukum pidana Islam adalah tidak dianggapnya tindakan tersebut sebagai tindak pidana. Hal ini sesuai dengan firman Allah Swt. dalam Q.s. al-Mâidah [5]: 33-34. Pada ayat 34 menjelaskan bahwa bagi orang-orang yang bertaubat, orang yang menghentikan perbuatan jahatnya karena kesadarannya sendiri, sebelum pihak berwenang menangkapnya, maka Allah Swt. Maha Pengampun dan Maha Penyayang atas mereka, maksudnya Allah memaafkan dan membebaskan mereka dari tuntutan hukum.

\section{Kritik Terhadap Pasal 10 dan 11}

Pasal 10 dan 11 menyebutkan bahwa setiap orang yang membantu atau melakukan percobaan, merencanakan atau melakukan pemufakatan jahat untuk melakukan tindak pidana perdagangan orang, dipidana dengan pidana yang sama seperti pelaku tindak pidana perdagangan 
orang. Pasal tersebut mengatur bahwa pelaku yang memenuhi delik perbantuan, percobaan, dan pemufakatan jahat dipidana dengan pidana yang sama yang diancamkan kepada pelaku delik. Hal ini berbeda dengan pengaturan Pasal 53 ayat (2) KUHP tentang percobaan bahwa, "Maksimum pidana pokok terhadap kejahatan, dalam hal percobaan dapat dikurangi sepertiga”. Menurut Eddy O. S. Hiariej ketentuan Pasal 52 ayat (2) adalah karena percobaan merupakan delik yang tidak sempurna. ${ }^{13}$ Begitu pula dengan pembantuan sebagaimana dinyatakan dalam Pasal 56 dan 57 KUHP. Pasal 56 dan 57 mengatur ancaman pidana bagi pelaku pembantuan dikurangi sepertiga dari pidana pokoknya.

Pasal 10 dan 11 juga berbeda dengan aturan dalam hukum pidana Islam. Penentuan mengenai penjatuhan ancaman pidana terhadap suatu perbuatan dalam hukum pidana Islam justeru lebih ketat. Suatu perbuatan dalam hukum pidana Islam dimaknai dengan proses yang saling bersambung hingga terbentuk suatu tindakan untuk mencapai tujuan yang dikehendakinya. Fase-fase rangkaian perbuatan dalam hukum pidana Islam dikelompokkan ke dalam tiga fase, yaitu (1) fase pemikiran dan perencanaan; (2) fase persiapan; dan (3) fase pelaksanaan. ${ }^{14}$

Fase pemikiran dan perencanaan merupakan fase awal dari suatu tindak perbuatan dimana dalam fase ini, seseorang baru terbatas pada penggunaan akal mereka untuk memikirkan suatu tindakan yang akan dilaksanakan. Batasan fase ini adalah belum adanyasuatu tindakan yang dilakukan dalam arti tindakan aktif. Apabila seseorang sudah mengaktualisasikan apa yang telah menjadi hasil pikirannya, meski baru terbatas pada fase persiapan, maka tindakan tersebut sudah tidak dapat lagi dimasukkan sebagai fase perencanaan. Dalam Islam niat memiliki peranan penting, sebagaimana disebutkan dalam hadits Riwayat Bukhârî bahwa: "Sesungguhnya suatu perbuatan sangat bergantung pada niat". ${ }^{15}$

${ }^{13}$ Eddy O. S. Hiariej, Prinsip-prinsip Hukum Pidana (Yogyakarta: Cahaya Atma Pustaka, 2014), h. 279.

${ }^{14}$ Ahmad Hanafi, Asas-asas Hukum Pidana Islam, h. 121.

${ }^{15}$ Al-Bukhârî, Shahîhal-Bukhârî, 1 (Bayrût: Dâr al-Fikr, 1994), h. 23, (Hadis nomor 54). 
Inti dari hadis tersebut secara tidak langsung mengindikasikan bahwa niat dan perbuatan adalah sesuatu kegiatan yang berbeda namun tidak dapat dipisahkan. Memikirkan dan merencanakan suatu jarimah tidak dianggap maksiat sehingga tidak dapat dijatuhi hukuman. ${ }^{16}$

Fase perencanaan kemudian dilanjutkan dengan fase persiapan, yaitu fase untuk mempersiapkan peralatan yang dibutuhkan untuk melakukan suatu tindak pidana, misalnya membeli senjata, memesan kunci palsu, atau menyiapkan peralatan lainnya. Batasan fase persiapan adalah pelaksanaan dari bagian suatu rencana, namun belum sampai pada bagian utama dari tindak pidana. Fase persiapan juga tidak dianggap maksiat yang dapat dihukum, kecuali apabila perbuatan persiapan itu dipandang sebagai maksiat. ${ }^{17}$

Fase ketiga, yaitu fase pelaksanaan. Fase di mana perbuatan seseorang sudah dapat dikenakan sanksi apabila perbuatannya merupakan perbuatan maksiat meskipun belum selesai. ${ }^{18}$ Maksudnya, meski perbuatan tersebut belum sampai pada tujuan akhir dari perencanaan namun telah mengandung aspek maksiat atau pelanggaran hak, baik hak individu maupun hak sosial. Dengan demikian tindak pidana percobaan, perencanaan, dan pemufakatan sebagaimana tercantum dalam Pasal 10 dan 11 tersebut, menurut hukum pidana Islam termasuk pada fase pertama dan kedua, hukumannya tidak sama dengan kejahatan yang berhasil dilaksanakan sampai tujuannya. Pelaku dijatuhi pidana sesuai dengan kejahatan yang sedang dilakukan. Hal ini sesuai dengan kaidah fikih:

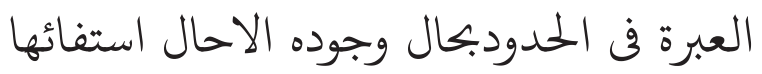

Pegangan dalam menentukan tindak pidana hudûd adalah waktu dilakukannya tindak pidana tersebut bukan pada waktu sempurnanya. ${ }^{19}$

\footnotetext{
${ }^{16}$ A. Djazuli, Fiqh Jinayah (Upaya Menanggulangi Kejahatan dalam Islam), h. 22.

${ }^{17}$ Ahmad Hanafi, Asas-asas Hukum Pidana Islam, h. 122.

${ }^{18}$ A. Djazuli, Fiqh Jinayah (Upaya Menanggulangi Kejahatan dalam Islam), h. 22.

${ }^{19}$ A. Djazuli, Kaidah-kaidah Fiqih (Jakarta: Prenada Media, 2006), h. 142.
} 


\section{Kritik Terhadap Jenis Pidana}

Berdasarkan Pasal 2,3,4,5,6, dan 12 UU PTPPO, ancaman pidana bagi pelaku tindak pidana perdagangan orang paling singkat 3 (tiga) tahun dan paling lama 15 (lima belas) tahun, serta pidana denda paling sedikit Rp. 120.000.000,00 (seratus dua puluh juta rupiah) dan paling banyak Rp. 600.000.000,00 (enam ratus juta rupiah). Lama pidana yang diancam oleh Pasal 9 adalah pidana penjara paling singkat 1 (satu) tahun dan paling lama 6 (enam) tahun, serta pidana denda paling sedikit Rp. 40.000.000,00 (empat puluh juta rupiah) dan paling banyak Rp.240.000.000,00 (dua ratus empat puluh juta rupiah). Lama pidana yang diancamkan Pasal 19 dan 20 adalah pidana penjara paling singkat 1 (satu) tahun dan paling lama 7 (tujuh) tahun, serta denda paling sedikit Rp. 40.000.000,00 (empat puluh juta rupiah) dan paling banyak Rp. 280.000.000,00 (dua ratus delapan puluh juta rupiah). Lama pidana yang diancam oleh Pasal 21 ayat (1), Pasal 22, dan Pasal 23 adalah pidana penjara paling singkat 1 (satu) tahun dan paling lama 5 (lima) tahun, serta pidana denda paling sedikit Rp. 40.000.000,00 (empat puluh juta rupiah) dan paling banyak Rp. 200.000.000,00 (dua ratus juta rupiah). Lama pidana yang diancamkan Pasal 24 adalah pidana penjara paling singkat 3 (tiga) tahun dan paling lama 7 (tujuh) tahun, serta pidana denda paling sedikit Rp. 120.000.000,00 (seratus dua puluh juta rupiah) dan paling banyak Rp. 280.000.000,00 (dua ratus delapan puluh juta rupiah). ${ }^{20}$ Selanjutnya menurut Pasal 25 jika terpidana tidak mampu membayar pidana denda, maka terpidana dapat dijatuhi pidana pengganti berupa kurungan paling lama 1 (satu) tahun.

Pasal-pasal tersebut semuanya mengatur tentang sanksi pidana bagi pelaku tindak pidana perdagangan orang. Jenis pidana yang paling banyak diancamkan adalah pidana penjara dan denda. Ancaman pidana ini tidak sepenuhnya cocok diancamkan kepada pelaku delik perdagangan orang karena pidana penjara masih banyak kekurangan yang harus diperbaiki supaya pemidanaan yang dijatuhkan kepada pelaku kejahatan tidak menimbulkan efek negatif bagi pelaku dan keluarganya, maupun kepada

${ }^{20}$ Dede Kania, "Pidana Penjara dalam Pembaharuan Hukum Pidana Indonesia," Jurnal Yustisia, no. 89 (Mei-Agustus 2014): h. 27. 
masyarakat dan negara. Hal ini disebabkan: (1) banyaknya pelaku TPPO yang dipenjara akan membebani anggaran negara, padahal anggaran ini bisa dialihkan untuk hal lain yang dapat mengurangi angka kemiskinan di Indonesia; (2) jenis delik berkaitan dengan perdagangan orang sangat beragam, mulai dari yang ringan sampai yang sangat berat. Oleh karena itu, ancaman pidana pun harus disesuaikan dengan jenis delik yang dilakukan, misalnya apabila delik diancam dengan pemberatan karena melakukan kekerasan, perkosaan, bahkan pembunuhan; (3) ancaman pidana dalam Undang-Undang Nomor 21 Tahun 2007 belum sepenuhnya mencerminkan tujuan dari pemidanaan itu sendiri, diantaranya adalah untuk menjerakan pelaku delik. Terbukti dengan masih maraknya delik perdagangan orang, modus operandinya pun terus mengalami perkembangan yang signifikan. Ancaman pidana kurungan sebagai pengganti pidana denda juga perlu dipertimbangkan, berdasarkan kualifikasi delik yang dilakukan dan dengan melihat dampak delik terhadap korban; (4) UU PTTPO menggunakan sistem minimum dalam penjatuhan pidana, namun tidak ditetapkan dengan jelas indikator penjatuhan pidana minimum terhadap suatu delik.

\section{Kritik Terhadap Tidak Adanya Kualifikasi Kejahatan dan Pelanggaran}

Undang-Undang Nomor 21 Tahun 2007 tentang Pemberantasan Tindak Pidana Perdagangan Orang sebagaimana disebutkan dalam Pasal 10 hanya mengatur tentang delik percobaan dan pembantuan secara terbatas, hanya untuk Pasal 2,3, 4, 5, dan 6. Sedangkan untuk Pasal 19, 20, 21, 22, 23, dan 24 tidak ada pengaturan delik tersebut. Dengan demikian diketahui bahwa, UU PTPPO tidak menegaskan kualifikasi antara delik kejatahan dan pelanggaran secara tegas. Hal ini tentu saja dapat menimbulkan masalah, karena UU PTPPO terikat kepada KUHP. UU PTPPO juga tidak mengatur masalah percobaan dan pembantuan. Akibat hukum dari tidak dibedakannya delik kejahatan dan pelanggaran bukan hanya terkait percobaan dan pembantuan, melainkan juga termasuk masalah concursus, daluarsa penuntutan dan pelaksanaan pidana, dan pemberlakuan asas nasional aktif. 


\section{Kelebihan Hukum Pidana Islam Dibandingkan Undang-Undang Nomor 21 Tahun 2007 dalamPemberantasan Tindak Pidana Perdagangan Orang}

Secara konseptual, setidaknya terdapat 7 (tujuh) keunggulan hukum pidana Islam dibandingkan hukum positif. Pertama, dalam perspektif hukum pidana Islam, sanksi pidana terhadap pelaku tindak pidana perdagangan orang tidak dapat hanya disandarkan pada ketentuan sanksi yang dimaksud dalam UU PTPPO, melainkan disandarkan pada jenis dan kualitas delik. Hal ini lebih mencerminkan keadilan dalam menentukan hukuman, dibandingkan dengan sanksi dalam UU PTPPO yang menyamakan sanksi dari setiap perbuatan

Kedua, sanksi dalam hukum pidana Islam bersifat zawâjir (membuat jera di dunia) dan jawâbir (menghapus dosa di akhirat). Sistem pidana Islam berdimensi dunia dan akhirat. Sifat zawâjir dalam hukum pidana Islam, tidak hanya menjerakan pelaku melainkan juga manusia lain yang menyaksikan eksekusi dari pidana tersebut, sehingga ia tidak akan melakukan kejahatan serupa. Misalnya dengan menyaksikan eksekusi qishâsh bagi pelaku pembunuhan disengaja, akan membuat orang enggan untuk membunuh, sehingga nyawa manusia terpelihara dengan baik sebagaimana dijelaskan Allah Swt. dalam Q.s.al-Baqarah [2] ayat 179 yang berbunyi:

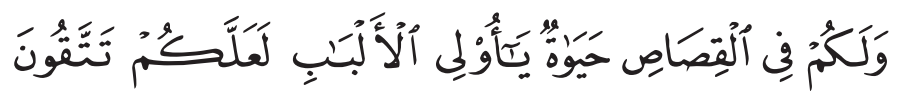

Dan dalam qishâsh itu ada (jaminan kelangsungan) hidup bagimu, hai orang-orang yang berakal, supaya kamu bertakwa.

Ketiga, hukum pidana Islam berasal dari Allah Swt, Dzat Yang Maha Mengetahui perihal manusia secara sempurna termasuk gerak gerik hak dan kecenderungan naluriah manusia. Tentu saja berbeda dengan hukum buatan manusia yang tidak dapat memberikan jaminan atas penyelesaian persoalan masyarakat dengan tuntas karena lahir dari keterbatasan akal manusia. Allah Swt. berfirman dalam Q.s. al-Mâidah [5]: 50 yang berbunyi:

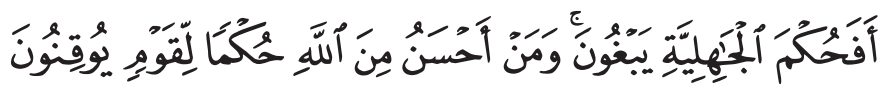


Apakah hukum Jahiliyah yang mereka kehendaki, dan (bukum) siapakah yang lebih baik daripada (hukum) Allah bagi orang-orang yang yakin?

Keempat, sebagai implikasi dari keunggulan ketiga, maka keunggulan berikutnya adalah sistem pidana Islam bersifat tetap (dawâm), konsisten, dan tidak berubah-ubah mengikuti situasi, kondisi, waktu, dan tempat. ${ }^{21}$ Sifat ini berbeda dengan sistem pidana konvensional yang tidak memiliki sifat konsisten, ia akan selalu berubah-ubah mengikuti kehendak manusia sesuai dengan situasi, kondisi, waktu, dan tempat.

Kelima, dalam sistem pidana Islam, peluang permainan hukum dan peradilan sangat kecil. Ini terutama karena hukum pidana Islam bersifat spiritual, yang menunjukkan ketakwaan seseorang kepada Allah Swt. ketika menjalankan hukum pidana Islam.

Keenam, dalam sistem pidana Islam, seorang qâdli memiliki independensi tinggi dengan tidak dapat dibatalkannya vonis yang dijatuhkan kepadanya. Kaidah fikih menyebutkan bahwa, "Ijtihad tidak dapat dibatalkan dengan ijtihad yang semisalnya." ${ }^{22}$ Artinya vonis hakim sebagai hasil ijtihadnya, tidak dapat dibatalkan oleh ijtihad yang dihasilkan hakim lainnya. Oleh karena itu, sistem pidana Islam tidak mengenal upaya hukum banding. Dalam sistem pidana Islam, sekali putusan dijatuhkan maka ia berlaku secara mengikat dan langsung dijalankan, kecuali jika vonis salah, maka wajib dibatalkan.

Ketujuh, tindak pidana perdagangan orang merupakan jenis kejahatan yang trans-nasional. Oleh karena itu, Pasal 59 UU PTPPO mengatur tentang kerja sama internasional dan peran serta masyarakat dalam menangani tindak pidana perdagangan orang. Dalam KUHP Indonesia secara tersirat disebutkan beberapa asas yang menjadi landasan bagi pembentukan serta pemberlakuan hukum pidana atas suatu peristiwa pidanayakni asas teritorial, asas personalitas aktif, asas personalitas pasif, dan asas universal. Pemberlakuan asas universal ini hanya dapat dilakukan terhadap kejahatan yang dianggap sebagai musuh bersama umat manusia

21 'Abd. al-Qâdir 'Awdah, al-Tasyrî‘ al-Jinâîal-Islâmî: Muqâranâ bi al-Qanûn al-Wadl'̂̀, 1 (Bayrût: Dâr al-Kitâb al-'Arâb, t.t.), h. 24-25.

${ }^{22}$ A. Djazuli, Kaidah-kaidah Fiqih, h. 91. 
(hostis generis). Berdasarkan asas ini, pelaku kejahatan dapat dipidana tanpa melihat kewarganegaraannya. Tujuan dari adanya asas universal adalah untuk menjamin adanya negara yang menghukum kejahatan tersebut. ${ }^{23}$

Pemberlakuan asas universal dalam hukum pidana Islam adalah berdasarkan pandangan, bahwa setiap negara Islam dianggap sebagai wakil bagi negara Islam lainnya untuk menghukum pelaku kejahatan berdasarkan ketentuan hukum pidana Islam. ${ }^{24}$ Ketentuan tersebut, berlaku terhadap kejahatan yang sudah ditetapkan dengan jelas bentuk dan hukumannya, berupa hudûd dan qishâsh. Selama pelaku dihukumi berdasarkan ketentuan hukum pidana Islam, maka dianggap cukup dalam mengatasi kejahatan di masyarakat. Hal ini berbeda dengan hukum positif, suatu kejahatan yang melibatkan dua negara atau lebih hanya dapat dihukum apabila kejahatan tersebut telah disepakati oleh negaranegara yang bersangkutan sebagai suatu kejahatan.

Keistimewaan lain dari hukum pidana Islam, adalah: (1) lebih efektif ${ }^{25}$ dan efisien; (2) bernilai religius dan memiliki suasana spiritual; (3) mengeliminir dan menimalkan kejahatan. Efektivitas tidak dapat diukur dengan lenyapnya kejahatan di bumi. Sistem reformatif tidak cukup untuk mengeliminir; (4) dapat menanggulangi modus operandi kejahatan modern dengan sistem penghukuman yang bersifat represif; (5) sistem reformatif dikenakan pada kejahatan ringan dan sistem retributif

${ }^{23}$ Wirjono Prodjodikoro, Asas-asas Hukum Pidana di Indonesia (Bandung: Refika Aditama, 2003), h. 57.

${ }^{24}$ Ahmad Hanafi, Asas-asas Hukum Pidana Islam, h. 104.

25 Sam S. Souryal menjelaskan bahwa sifat efektif syariat Islam disebabkan 5 (lima) hal: (1) syariat terus menerus mendorong perbaikan individu dan menyucikan kesadarannya dengan ide-ide Islam yang tinggi dan moralitas yang luhur; (2) syariat dengan seimbang memperingatkan manusia untuk tidak melakukan kejahatan dengan dan mengancam pelakunya dengan hukuman berat di dunia dan di akhirat; (3) syariat memerintahkan umat Islam untuk saling tolong menolong dalam kebaikan dan kesabaran dengan memberikan bimbingan, dorongan moral, dan pengajaran agama; (4) syariat mencegah kejahatan kejahatan dengan menutup jalan yang dapat menyebabkan dilakukannya perbuatan itu; dan (5) syariat mempersiapkan umat Islam, sebagai antisipasi kecenderungan moral manusia, dengan jalan mendukung perkawinan di usia muda, membolehkan poligami secara terkontrol, dan mewajibkan bagi orang-orang yang mampu untuk mengeluarkan sebagian hartanya bagi orang-orang yang kurang beruntung (mewajibkan zakat). Sam Souryal, Religious Training as a Method of Social Control,dalam Topo Santoso, Membumikan Hukum Pidana Islam: Penegakan Syariat dalam Wacana dan Agenda (Jakarta: Gema Insani Press, 2003), h. 137. 
dikenakan pada kejahatan berat; (6) perhatian terhadap tindak pidana dan terpidana menjadi hal penting sejak abad keenam masehi pada konsep pemidanaan dalam Islam; (7) pidana Islam tidak kejam, ${ }^{26}$ terdapat hikmah dalam pidana yang berat, yang terbukti dapat mengurangi angka kejahatan; (8) pidana Islam sangat bijaksana. Pencuri dipotong tangannya tidak dilenyapkan jiwanya; pezina dicambuk tidak dipotong alat kelaminnya; pendusta dicambuk tidak dipotong lidahnya. Hal itu bukti sifat kasih sayang, hikmah, rahmat, dan keadilan pada konsep pemidanaan dalam Islam.

\section{Konsep Hukum Pidana Islam dalam Menangani Tindak Pidana Perdagangan Orang}

Perdagangan orang merupakan kezaliman yang sangat bertentangan dengan ajaran Islam. Salah satu misi dakwah ketika Islam datang adalah menghapus perdagangan orang atau perbudakan di muka mukabumi. Islam menawarkan solusi terhadap masalah perbudakan yaitu dengan memasukkan budak (riqâb) dan orang yang dililit hutang (ghârimin) sebagai pihak-pihak yang berhak menerima zakat. Salah satu faktor penyebab terjadinya trafficking adalah kemiskinan dan lilitan hutang, sehingga mayoritas korban trafficking adalah orang-orang yang berasal dari keluarga miskin dan berada dalam kelas ekonomi rendah. Oleh karena itu, korban trafficking pada dasarnya berhak menerima zakat.

Pandangan Islam tersebut perlu ditransformasikan untuk menangani masalah trafficking secara praktis. Meski tidak dalam pengertian memberikan zakat secara langsung terhadap korban trafficking, namun yang pasti solusi tersebut dapat bermanfaat bagi pemberantasan masalah trafficking secara umum. Solusi yang dimaksud adalah memfungsikan zakat sebagai pendukung dalam pendanaan program-program pemberantasan trafficking.

Upaya pemberantasan trafficking dapat berjalan efektif apabila didukung oleh pendanaan yang baik. Hal ini karena trafficking sendiri merupakan bisnis ketiga paling menguntungkan setelah narkoba dan

${ }^{26}$ Otje Salman dan Anthon F. Susanto, Menyikapi dan Memaknai Syariat Islam Secara Global dan Nasional: Dinamika Peradaban, Gagasan \& Sketsa Tematis (Bandung: Refika Aditama, 2004), h. 82. 
senjata. Sebagaimana perbudakan pada masa lalu, trafficking kini melibatkan pemodal kelas kakap. Supaya mendapatan dana yang besar untuk menangani tindak pidana trafficking, maka setiap badan yang mengelola zakat semestinya mengalokasikan pos riqâb dan ghârimin untuk membiayai gerakan anti trafficking. Dengan dukungan dana ini, maka masyarakat dapat lebih mudah merealisasikan sistem pencegahan trafficking secara menyeluruh, baik melalui pemberdayaan ekonomi para korban, meningkatkan pendidikannya, maupun dengan cara pembinaan nilai-nilai moral para korban.

\section{Formulasi Sanksi Pidana bagi Pelaku Tindak Pidana Perdagangan Orang}

Berbagai kebijakan (policy) yang dibuat pemerintah berkaitan dengan penanganan tindak pidana perdagangan orang, pada dasarnya relatif komprehensif. Namun, perlindungan hukum terhadap korban perdagangan manusia saat ini masih dirasakan kurang efektif. Hal ini terlihat dari sangat jarangnya pidana yang berat yang dijatuhkan oleh hakim terhadap pelaku tindak pidana perdagangan orang. Pidana yang dijatuhkan ternyata tidak dapat menimbulkan efek jera bagi para pelaku tindak pidana. Landasan kebijakan hukum pidana dalam Undang-Undang Nomor 21 Tahun 2007, selain untuk melindungi nilai-nilai kemanusiaan yang hidup dalam masyarakat dan untuk melindungi hak asasi manusia, adalah untuk menciptakan keadilan sebagai sarana dalam menciptakan kesejahteraan masyarakat. ${ }^{27}$ Karena itu, sistem pelaksanaan pidana yang diterapkan sebaiknya mengacu kepada sistem pemidanaan yang humanis (manusiawi), tentu saja dengan memperhatikan fleksibilitas pemidanaan dan modifikasi perubahan pemidanaan. Sistem ini memberikan kebebasan kepada hakim untuk memilih pidana yang paling sesuai dengan karakteristik atau kondisi pelaku dan dimungkinkan adanya perubahan pelaksanaan pidana disesuaikan dengan perkembangan atau kemajuan terpidana. Berkaitan dengan pemikiran tersebut, hukum Islam sebagai salah satu komponen hukum nasional, perlu memberi kontribusi terhadap

${ }^{27}$ Barda Nawawi Arief, Bunga Rampai Kebijakan Hukum Pidana (Perkembangan Penyusunan Konsep KUHP Baru) (Jakarta: Kencana, 2010), h. 38. 
perundang-undangan anti trafficking ke depan agar permasalahan besar bangsa ini dapat teratasi.

Menurut hukum pidana Islam, adanya persamaan sanksi dari setiap perbuatan dalam Undang-Undang Nomor 21 Tahun 2007 dipandang kurang tepat, bahkan tidak mencerminkan keadilan. Idealnya setiap tindakan tersebut baru dapat dikenakan hukuman sebagaimana dimaksud dalam Pasal 2 apabila telah memenuhi unsur delik pada pasal tersebut, yakni tindak pidana perdagangan orang. Jadi, dalam konteks hukum pidana Islam, selama tidak terkandung esensi tindak pidana perdagangan orang, maka orang tersebut tidak dapat dikenakan sanksi tindak pidana perdagangan orang. Oleh karena itu, berkaitan dengan TPPO, berdasarkan teori hukum pembangunan hukum ada dua cara yang dapat diperankan oleh hukum Islam dalam pembangunan nasional. Pertama, hukum Islam berperan dalam mengisi kekosongan dalam hukum positif, dimana hukum Islam dapat diberlakukan oleh negara sebagai hukum positif bagi umat Islam. Kedua, hukum Islam berperan sebagai sumber nilai yang memberi kontribusi terhadap aturan hukum yang dibuat. Karena itu, hukum tersebut bersifat umum, tidak memandang perbedaan agama, maka nilainilai hukum Islam dapat berlaku pula bagi seluruh warga negara.

Apabila memakai cara yang pertama, yakni hukum Islam dijadikan sebagai hukum positif, menurut kajian hukum pidana Islam, dalam konteks jarîmah ada beberapa jenis hukuman yang dapat dikenakan dengan klasifikasi sebagai berikut: (1) tindak pidana perdagangan orang yang disertai dengan tindak pidana pembunuh atau penganiayaan, maka dapat dikenakan pidana qishâsh-diyat disertai dengan ketentuan-ketentuan yang berlaku dalam qishâsh-diyat, (2) tindak pidana perdagangan orang yang disertai dengan tindak pidana pemerkosaan atau perzinaan, maka dapat dikenakan pidana hudûd disertai dengan ketentuan-ketentuan yang berlaku di dalamnya; dan (3) tindak pidana perdagangan orang yang tidak disertai dengan tindak pidana pembunuhan maupun penganiayaan dan pemerkosaan, meski hanya melakukan sebagian maupun seluruhnya, maka dapat dikenakan hukuman ta'zîr, baik dalam konteks sanksi sebagaimana dimaksud dalam Pasal 2 Undang-Undang Nomor 21 Tahun 2007, maupun ta'zîr di luar sanksi dalam pasal tersebut. 
Dengan demikian, sanksi bagi pelaku tindak pidana perdagangan menurut hukum pidana Islam tidak hanya terbatas pada sanksi yang terkandung dalam Pasal 2 Undang-Undang Nomor 21 Tahun 2007, melainkan dapat lebih berat atau lebih ringan sesuai dengan kadar tindakan yang diukur dari akibat kerugian yang ditimbulkan dari tindak pidana yang dilakukan. Hal ini sesuai dengan kaidah fikih:

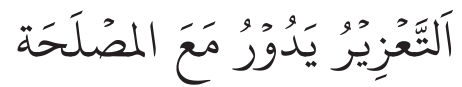

Berat ringannya sanksi ta'zîr diserahkan kepada imam (hakim) sesuai dengan besar kecilnya kejahatan yang dilakukan. ${ }^{28}$

Pemberian sanksi berdasarkan kadar tindakan yang diukur dari akibat kerugian yang dihasilkan dari tindak pidana merupakan cermin keadilan dalam hukum. Sedangkan apabila mengambil cara yang kedua, yakni hukum Islam berperan sebagai sumber nilai yang berlaku universal, maka pelaku tindak pidana perdagangan orang dapat dikenakan sanksi sebagai berikut:

Pertama, apabila eksploitasi tersebut berupa penjualan organ tubuh, yang didahului dengan pembunuhan korban, maka pelaku dapat dikenakan sanksi sebagaimana dimaksud dalam Undang-Undang Nomor 21 Tahun 2007, namun dengan hukuman yang maksimal, yakni penjara seumur hidup atau hukuman mati. Tetapi, hukuman tersebut dapat berubah menjadi diyat apabila ada pemaafan dari pihak keluarga korban. hukuman maksimal dibutuhkan karena kejahatan ini melanggar hak Allah dan hak 'Ibad sekaligus, maka had yang diberikan pun harus had al-'ala (hukuman tertinggi).

Kedua, apabila dalam eksploitasi tersebut disertai dengan beberapa tindak pidana, seperti perzinaan dan penganiayaan yang mengakibatkan korban misalnya, menderita gangguan jiwa berat atau kehamilan, maka pidana yang diberikan kepada pelaku adalah pidana gabungan dari masing-masing sanksi tindak pidana yang telah dilakukan dengan hukuman yang maksimal sebagaimana tercantum pada Pasal 7 ayat (1) dan Pasal 12.

28 'Abd al-Azîz Amîr, Al-Ta'zîrfî̀ al-Syarî́atal-Islâm (Bayrût: Dâr al-Fikr, 1969), h. 55. 
Ketiga, tindak pidana perdagangan orang berupa eksploitasi orang atau pemanfaatan kerja fisik yang tidak disertai dengan tindak pidana pembunuhan maupun penganiayaan dan pemerkosaan meski hanya melakukan sebagian atau seluruhnya, maka dapat dikenakan sanksi pidana ta'zîr, baik dalam konsteks sanksi sebagaimana dimaksud dalam Pasal 2 UU 21Tahun 2007 maupun ta'zîr di luar sanksi yang diatur dalam Pasal tersebut.

\section{Penutup}

Berdasarkan uraian di atas, penulis menyimpulkan bahwaUndangUndang Nomor 21 Tahun 2007 tentang Pemberantasan Tindak Pidana Perdagangan Orang (selanjutnya disebut UU PTPPO) memiliki tujuan yang sama dengan tujuan hukum pidana Islam, yaitu melindungi, mempertahankan, dan meningkatkan martabat manusia dengan berupaya memberi perlindungan dari tindak pidana perdagangan orang.

Perspektif hukum pidana Islam, undang-undang ini masih memerlukan penyempurnaan substansi hukum, sehingga dapat lebih mencerminkan kepastian dan keadilan hukum. Hal yang perlu disempurnakan diantaranya terkait dengan pengaturan ancaman pidana, yaitu dengan mengelompokkan sanksi pidana kepada ta'zîr, qishâsh-diyat, dan $\underline{\text { hudûd. }}$.

\section{Pustaka Acuan}

Azizurrahman, Syarif Hasyim "Pembaharuan Kebijakan Pidana Kejahatan Perdagangan Orang (Studi di Wilayah Perbatasan Kalimantan BaratSarawak)," Jurnal Yustisia, no. 89 (Mei-Agustus 2014): 88.

Agus, J. Azlaini (Komisi III DPR RI, Pansus RUU PTPPO DPR

RI) pada (Seminar Nasional Strategi Pemberantasan Tindak Pidana Perdagangan Orang dalam Perspektif Lokal, Nasional, dan Internasional, Universitas Jember, 27 Juni 2009).

Arief, Barda Nawawi. Pembaharuan Hukum Pidana dalam Perspektif Kajian Perbandingan. Bandung: Citra Aditya Bhakti, 2005. , Bunga Rampai Kebijakan Hukum Pidana (Perkembangan Penyusunan 
Konsep KUHP Baru). Jakarta: Kencana, 2010.

'Awdah, Abd. al-Qâdir. al-Tasyrî' al-Jinâî̀ al-Islâmî: Muqâranâ bi al-Qanûn al-Wadl'č, 1. Bayrût: Dâr al-Kitâb al-'Arâb, t.t..

Arief, Barda Nawawi. Bunga Rampai Kebijakan Hukum Pidana (Perkembangan Penyusunan Konsep KUHP Baru). Jakarta: Kencana, 2010. (DIHAPUS SUDAH PINDAH KE ATAS)

Ardianto, Syaifullah Yophi. "Perlindungan Hukum Terhadap Anak Sebagai Korban dari Tindak Pidana Perdagangan Orang di Kota Pekanbaru." Jurnal Ilmu Hukum Riau 3, no. 2 (2013).

Agustina, Shinta. "Perdagangan Perempuan dan Anak Sebagai

Kejahatan Transnasional: Permasalahan dan Penanggulangannya di Indonesia.” Jurnal Hukum Pro Justitia 24, no. 1 (2006).

Amîr, Abd al-Azîz. Al-Ta'zîrfí al-Syarî‘atal-Islâm. Bayrût: Dâr al-Fikr, 1969. Andreo, Daniel. “Analisis Juridis Terhadap Pertanggungjawaban Pidana Pelaku Percobaan Tindak Pidana Perdagangan Orang Menurut Undang-Undang Nomor 21 Tahun 2007 (Putusan Pengadilan Negeri Medan Nomor 1.642/Pid. B/2009/PN. Medan.” Jurnal Mahupiki 2, no. 01 (2012).

ANTARA News, Senin, 23 April 2012.

Bandung Ekspress, Kamis, 12 Oktober 2012.

Bukhârî, Al-. Shahîhal-Bukhârî, 1. Bayrût: Dâr al-Fikr, 1994.

Djazuli, A. Fiqh Jinayah (Upaya Menanggulangi Kejahatan dalam Islam). Jakarta: PT Raja Grafindo Persada, 2000.

Djazuli, A. Kaidah-kaidah Fiqih. Jakarta: Prenada Media, 2006.

Effendi, Erdianto. "Pemberantasan Perdagangan Orang dengan Sarana Hukum Pidana." Jurnal Cita Hukum 1, no. 1 (2013).

Fadilla, Nelsa. "Upaya Perlindungan Hukum Terhadap Anak Sebagai Korban Tindak Pidana Perdagangan Orang." Jurnal Hukum dan Peradilan 5, no. 2 (2016): 181-194.

Gunting, Sanofta DJ, Nurmala Waty, and Alwan Alwan. "Kebijakan Hukum Pidana dalam Menanggulangi Tindak Pidana Perdagangan Orang (Human Trafficking).” Jurnal Mahupiki 2, no. 1 (2013). 
Hanafi, Ahmad Asas-asas Hukum Pidana Islam. Jakarta: Bulan Bintang, 1990.

Hiariej, Eddy O. S. Prinsip-prinsip Hukum Pidana. Yogyakarta: Cahaya Atma Pustaka, 2014.

Hidayati, Maslihati Nur. "Upaya Pemberantasan dan Pencegahan Perdagangan Orang Melalui Hukum Internasional dan Hukum Positif Indonesia." Jurnal Al-Azhar Indonesia Seri Pranata Sosial 1, no. 3 (2012): 163-175.

Jayanti, Linda, Steven R. Sentinuwo, Oktavian A. Lantang, and Agustinus Jacobus. "Analisa Pola Penyalahgunaan Facebook Sebagai Alat Kejahatan Trafficking Menggunakan Data Mining." Jurnal Teknik Informatika Universitas Sam Ratulangi 8, no. 1 (2016).

Kania, Dede. "Pidana Penjara dalam Pembaharuan Hukum Pidana Indonesia,” Jurnal Yustisia, no. 89 (Mei-Agustus 2014): 27.

Kusuma, Ayu Amalia. "Efektivitas Undang-Undang Perlindungan Anak dalam Hubungan dengan Perlindungan Hukum Terhadap Anak Korban Perdagangan Orang di Indonesia." Lex Et Societatis 3, no. 1 (2015).

Manalu, Perdana Eliakhim, Suhaidi Suhaidi, Muhammad Hamdan, and Hasim Purba. "Sanksi Pidana terhadap Pelaku Tindak Pidana Perdagangan Orang (Studi Beberapa Putusan Pengadilan Negeri di Indonesia).” USU Law Journal 2, no. 3 (2014): 176-189.

Munthe, Riswan. "Perdagangan Orang (Trafficking) Sebagai Pelanggaran Hak Asasi Manusia." JUPIIS: Jurnal Pendidikan Ilmu-ilmu Sosial 7, no. 2 (2015): 184-192.

Nuraeny, Henny. "Penyuluhan Hukum Mengenai Undang-undang Nomor 21 Tahun 2007 Tentang Pemberantasan Tindak Pidana Perdagangan Orang Bagi Guru Bimbingan Konseling dan Siswa/Siswi SMK/ SMA/MA Se-kabupaten Cianjur." Journal of Empowerment 1, no. 1 (2017): 23-36. , and Tanti Kirana Utami. "The Victim Handling Model Of Human Trafficking Through Economic Independence.” Jurnal Dinamika Hukum 16, no. 2 (2016): 120-124. 
Niko, Nikodemus. "Kemiskinan sebagai Penyebab Strategis Praktik Humman Trafficking di Kawasan Perbatasan Jagoi Babang (IndonesiaMalaysia) Kalimantan Barat." In Prosiding Seminar Nasional Indocompac. 2016.

Prodjodikoro, Wirjono. Asas-asas Hukum Pidana di Indonesia. Bandung: Refika Aditama, 2003.

Santoso, Topo. Menggagas Hukum Pidana Islam: Penerapan Syariat Islam dalam Konteks Modernitas. Bandung: Asy-Syaamil Press \& Grafika, 2001.

Salman, Otje dan Anthon F. Susanto. Menyikapi dan Memaknai Syariat Islam Secara Global dan Nasional: Dinamika Peradaban, Gagasan \& Sketsa Tematis. Bandung: Refika Aditama, 2004.

Sari, Dwita Puspita, and Dessy Artina. "Penggunaan Sarana Non Penal oleh Pusat Pelayanan Terpadu Pemberdayaan Perempuan dan Anak Provinsi Riau dalam Pencegahan Tindak Pidana Perdagangan Anak di Bawah Umur Berdasarkan Undang-Undang Nomor 35 Tahun 2014 Atas Perubahan Undang-Undang Nomor 23 Tahun 2002 Tentang Perlindungan Anak." Jurnal Online Mahasiswa (JOM) Bidang Ilmu Hukum 4, no. 2 (2018): 1-15.

Sastriyani, Siti Hariti. "Perlindungan Perempuan dan Anak Korban Trafficking di Kabupaten Kapuas Hulu." Marwah: Jurnal Perempuan, Agama dan Jender 9, no. 2 (2010): 114-133.

Suhardin, Yohanes. "Tinjauan Yuridis Mengenai Perdagangan Orang dari Perspektif Hak Asasi Manusia.” Mimbar Hukum-Fakultas Hukum Universitas Gadjah Mada 20, no. 3 (2008): 473-486.

Suyûthî, Jalâl al-Dîn al-. al-Jâmial-Shaghîr, 1. Bayrût: Dâr al-Fikr, 73.

Souryal, Sam. "Religious Training as a Method of Social Control", dalam Topo Santoso. Membumikan Hukum Pidana Islam: Penegakan Syariat dalam Wacana dan Agenda. Jakarta: Gema Insani Press, 2003.

Sylvia, Ike. "Faktor Pendorong dan Penarik Perdagangan Orang (Human Trafficking) di Sumatera Barat.” Humanus 13, no. 2 (2014): 193-202.

US Departemen of Justice, "Trafficking in Person Report". Washington: US Departemen of Justice, 2002. 
Wardani, Ferica, and Faisyal Rani. "Peran Bali Process On People Smuggling, Traficking In Person And Related Transnational Crime (Bali Process) dalam Menangani Penyelundupan Manusia di Indonesia Pada Tahun 2008-2013." Jurnal Online Mahasiswa (JOM) Bidang Ilmu Sosial dan Ilmu Politik 2, no. 2 (2015): 1-15. 